\title{
Sockeye salmon population dynamics over the past 4000 years in Upper Russian Lake, south-central Alaska
}

\author{
Molly D. McCarthy (D) Daniel J. Rinella · Bruce P. Finney
}

Received: 1 June 2017/Accepted: 2 March 2018/Published online: 13 March 2018

(C) The Author(s) 2018

\begin{abstract}
Stable nitrogen isotope $\left(\delta^{15} \mathrm{~N}\right)$ data from sediment cores taken in clear-water Upper Russian Lake (Kenai River Watershed, Alaska, USA) indicate that sockeye salmon (Oncorhynchus nerka) populations varied significantly over the past 4000 years, with a prominent $\sim 650$-year period of lower salmon abundance from $\sim 100 \mathrm{BCE}$ to $550 \mathrm{CE}$. Sediment characteristics during this $\sim 650$-year interval reflect glacial sediment input, which may have contributed to the salmon decline by degrading spawning habitat and reducing carrying capacity. The decline, however,
\end{abstract}

M. D. McCarthy $(\bowtie) \cdot$ D. J. Rinella

Department of Biological Sciences, University of Alaska Anchorage, Beatrice G McDonald Hall, 2400 W Campus Dr, Anchorage, AK 99508, USA

e-mail: mmccarthy3@alaska.edu

D. J. Rinella

e-mail: daniel_rinella@fws.gov

D. J. Rinella

Alaska Center for Conservation Science and Department of Biological Sciences, University of Alaska Anchorage, Anchorage, AK 99508, USA

B. P. Finney

Departments of Biological Sciences and Geosciences, Idaho State University, Pocatello, ID 83209, USA

e-mail: finney@isu.edu

Present Address:

D. J. Rinella

U.S. Fish and Wildlife Service, Anchorage Fish and Wildlife Conservation Office, Anchorage, AK 99507, USA coincides with large reductions in sockeye salmon abundance identified previously in Karluk and Akalura lakes on Kodiak Island, $>400 \mathrm{~km}$ southwest, supporting the possibility of regionally synchronous, multi-centennial production regimes that may originate from shifts in oceanographic conditions such as biological productivity in the northeastern Pacific Ocean. Under such a scenario, coincidence with watershed glacial activity indicates a common driver, i.e. regional climate change. Climate conditions that led to significant glacial advances in this part of the Kenai Peninsula (cold and/or wet conditions) may have also created unfavorable ocean conditions during critical periods in the marine phase for these stocks of Gulf of Alaska sockeye salmon. Future climate projections and management strategies should focus on how climate regimes impact not only prey availability for salmon at sea, but also local conditions for spawners and juveniles.

Keywords Salmon · Nitrogen - Sediment - Alaska · $\delta^{15} \mathrm{~N} \cdot$ Climate

\section{Introduction}

Paleolimnological analyses have led to reconstructions of sockeye salmon (Oncorhynchus nerka) abundance spanning hundreds or thousands of years in 
many nursery lakes (Finney 1998, 2000, 2002; Gregory-Eaves et al. 2003; Rogers et al. 2013). These insights are possible because adult sockeye salmon, after gaining nearly all of their body mass at sea, return to natal river systems where they spawn and die, primarily in lakes and associated feeder streams. Marine-derived nitrogen (MDN) from decomposing salmon carcasses, which is enriched in ${ }^{15} \mathrm{~N}$ relative to watershed sources, is subsequently preserved in lake sediments and represents a time-series proxy of past abundance that can be sampled by coring lake sediments.

A synthesis of paleolimnological data spanning $\sim 500$ years from 20 nursery lakes in southwestern and south-central Alaska, the center of wild sockeye salmon abundance, reveals substantial shifts in salmon productivity within individual lakes that often lasted for decades or centuries (Rogers et al. 2013). These productivity regimes were often asynchronous among lakes, presumably related to differential responses of habitats and salmon populations to regional climatic conditions, resulting in a "portfolio effect" that stabilizes regional salmon returns over time (Rogers et al. 2013). When viewed across longer time scales, however, there is evidence for regionally coherent climate-related shifts in abundance that may synchronize the dynamics of different populations. Paleolimnological data from two nursery lakes on Kodiak Island, covering 2200 years, showed large, synchronous declines in sockeye salmon that began around $\sim 100 \mathrm{BCE}$ and lasted for several hundred years (Finney et al. 2002). Examination of temporal variation at similarly long timescales in distant river systems will provide insights into the temporal and spatial scales over which population trends of different stocks are synchronized or not.

The Kenai River is the most productive sockeye salmon system in south-central Alaska's Cook Inlet Watershed, producing over half of the Inlet's average annual return of 5.2 million sockeye salmon (Willette and Shields 2015; Schoen et al. 2017). The Cook Inlet commercial fishery harvests an average of 2.9 million sockeye salmon with an ex-vessel value of $\$ 26.3$ million (1966-2014 data; Shields and Dupuis 2016). Within a 3-h drive of nearly two-thirds of Alaska's human population, the Kenai River also supports the most popular personal-use and sport fisheries in Alaska. Despite the importance of the Kenai River's sockeye salmon and the insights that may be gained from investigating trends in long-term abundance, paleolimnological reconstructions of salmon abundance had not been conducted previously.

Study area

The Kenai River Watershed (Kenai Peninsula, southcentral Alaska) drains $56,600 \mathrm{~km}^{2}$ of icefields, rugged mountains, and boreal forest (Fig. 1). The mainstem Kenai River begins at the outlet of Kenai Lake and flows $132 \mathrm{~km}$ westward to Cook Inlet, passing through Skilak Lake along the way. Several tributaries drain montane glaciers in the eastern part of the watershed, carrying cold, sediment-rich meltwater into Kenai Lake, Skilak Lake, and the mainstem Kenai River. Numerous clear-water tributaries also join the system, ranging from montane streams that drain persistent snowpack to lowland streams that drain extensive forest and wetlands. Additional lakes are found on both glacial and clear-water tributaries.

This mosaic of freshwater habitats supports all five species of North American Pacific salmon, with sockeye being the most abundant. The total sockeye salmon run to the Kenai River Watershed averages 3.1 million fish; on average, 2.4 million of these are harvested and 700,000 escape to spawn and die (1976-2008 average; Tobias and Willette 2013). Spawning occurs throughout much of the watershed in multiple substocks and juveniles typically rear in several different glacier-fed and clear-water lakes for 1 or 2 years before going to sea.

We chose to study Upper Russian Lake (Fig. 1; $60.339^{\circ} \mathrm{N}, 149.880^{\circ} \mathrm{W}$ ) because it is the Kenai River Watershed's most productive clear-water sockeye salmon nursery lake (DeCino and Willette $2011,2014)$ and because its relatively high escapement density $\left(\sim 20,000\right.$ spawners $\left./ \mathrm{km}^{2}\right)$ makes it amenable to paleolimnological reconstruction of salmon abundance (Finney et al. 2000). Upper Russian Lake is a relatively small lake $\left(4.6 \mathrm{~km}^{2}\right)$ drained by the Russian River, which in turn flows into the Kenai River $119 \mathrm{~km}$ upstream from its mouth at Cook Inlet. Two genetically distinct sockeye salmon runs use this river system: the early run spawns in early July in Upper Russian Lake's main tributary and the late run spawns in August throughout Upper Russian Lake, in the main tributary, and in the lake outlet (Nelson 1983). Escapement to the Russian River, which has been counted annually at a weir on the lower Russian 


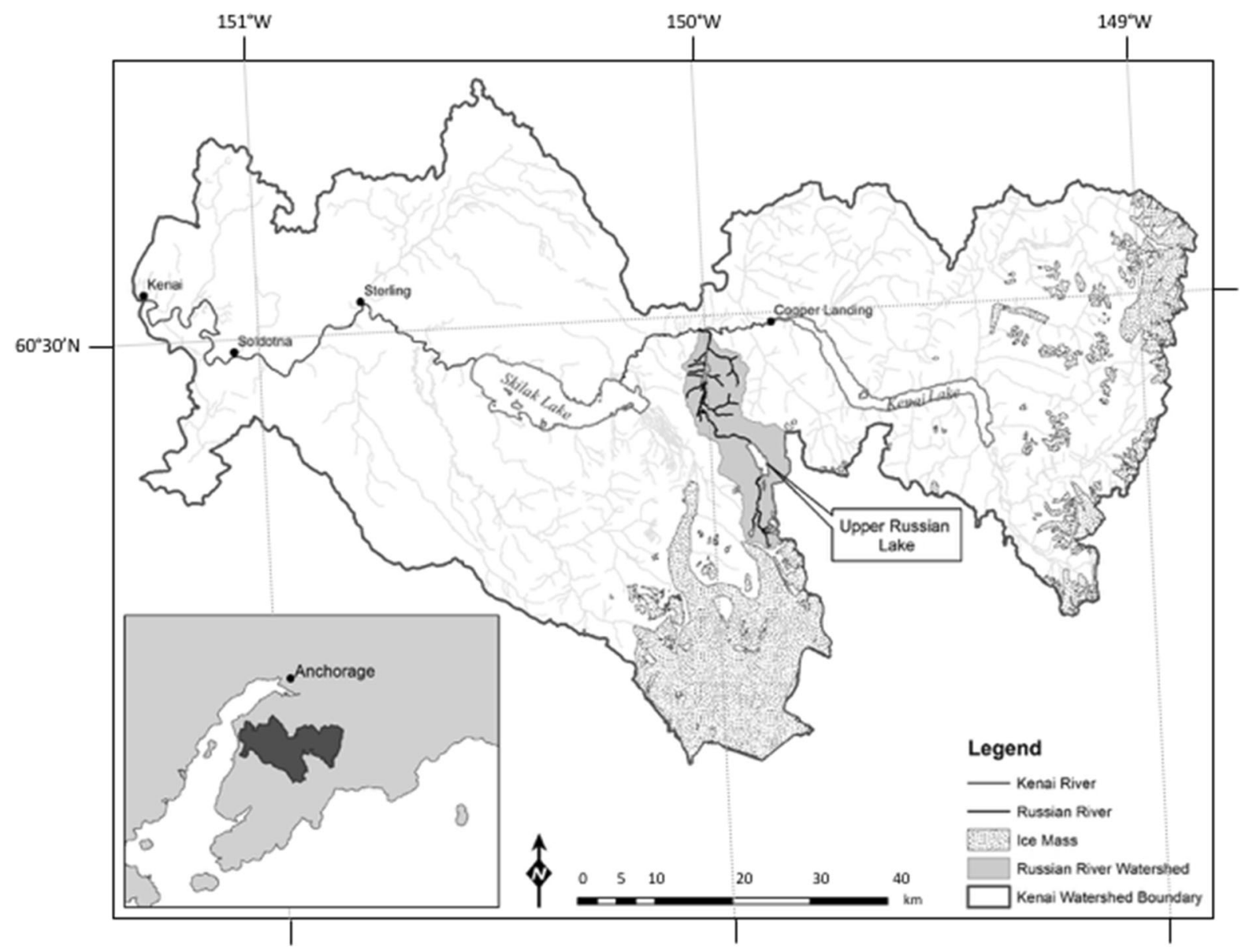

Fig. 1 The Kenai River watershed, including the Russian River watershed (highlighted in gray)

River since 1965, ranges from $\sim 2000$ to 86,000 for the early run and $\sim 21,000-158,000$ for the late run (Fair et al. 2013) (Table 1).

The purpose of this study was to expand our knowledge of past salmon populations in south-central Alaska. Our objectives were (1) to reconstruct relative changes in past salmon abundance over multi-millennial timescales using sediment $\delta^{15} \mathrm{~N}$ in Upper Russian Lake (2) compare our results to previously published paleolimnological reconstructions of salmon abundance, and (3) examine paleoclimate changes that may have influenced salmon productivity over time. Although our focus was on Alaskan systems, understanding the nature of past variability, and any connections to climate change, have broad implications for salmon conservation and management throughout their range.

\section{Materials and methods}

Sediment coring and analysis

We collected twelve undisturbed surface sediment cores that ranged from 0.5 to $1.2 \mathrm{~m}$ in length from Upper Russian Lake between 2014 and 2015 using a hand-operated universal percussion corer (Universal Percussion Corer, Aquatic Research Instruments, Hope, ID). Most cores were obtained from the southern end of the lake in a deep, flat basin. We used Zorbitrol and floral foam immediately upon obtaining cores to preserve surface sediments, which remained intact through shipping. We shipped whole cores to the National Lacustrine Core (LacCore) Facility at the University of Minnesota where they were run through a Geotek Multi-Sensor Core Logger (MSCL) to measure magnetic susceptibility and gamma density, 
Table 1 Limnological characteristics for Upper Russian Lake

\begin{tabular}{lllllll}
\hline $\begin{array}{l}\text { Water residence } \\
\text { time }(\text { years })\end{array}$ & $\begin{array}{l}\text { Escapement density } \\
\left(\text { spawners } / \mathrm{km}^{2}\right)\end{array}$ & $\begin{array}{l}\text { Surface } \\
\text { Area }\left(\mathrm{km}^{2}\right)\end{array}$ & $\begin{array}{l}\text { Volume } \\
\left(\times 10^{6} \mathrm{~m}^{3}\right)\end{array}$ & $\begin{array}{l}\text { Turbidity } \\
(\mathrm{NTU})\end{array}$ & $\begin{array}{l}\text { Euphotic zone } \\
\text { depth }(\mathrm{m})\end{array}$ & $\begin{array}{l}\text { Zooplankton density } \\
\left(\mathrm{mg} \mathrm{m} \mathrm{m}^{-2}\right)\end{array}$ \\
\hline$\sim 1.1_{(1)}$ & $\sim 20,000$ & $4.6_{(3)}$ & $122_{(3)}$ & $\mathrm{n} / \mathrm{a}$ & $13.0_{(1)}$ & $\sim 1400_{(2)}$ \\
\hline
\end{tabular}

Data are from Koenings et al. (1986) (1); Koenings and Kyle (1997) (2); Spafard and Edmundson (2000) (3); N/A indicates that no data could be found

then split and imaged. We chose a $\sim 110$-cm-long master core based on the presence of terrestrial plant macrofossils (for radiocarbon dating), uniform horizontal laminations, and the absence of turbidites or other event-driven sediment deposits (Fig. 2). We believe the master core covers the longest period of time, based on the presence of a distinct white tephra (volcanic ash) deposit located near the base of the core, which was not present in other cores (Fig. 2).

We subsampled sediment from the master core continuously at $0.5-\mathrm{cm}$ intervals, yielding a total of 215 subsamples. We mixed each of these subsamples and removed small aliquots that were homogenized, dried, and subsequently analyzed for $\delta^{15} \mathrm{~N}$ as a proxy for past salmon abundance, in addition to $\% \mathrm{C}, \% \mathrm{~N}$, and $\delta^{13} \mathrm{C}$. These analyses were run on a Costech ECS 4010 elemental analyzer (Costech, Valencia, CA) in line with a Thermo Scientific Delta V Advantage continuous-flow isotope ratio mass spectrometer (Thermo Scientific, Bremen, Germany) calibrated with international reference standards from the International Atomic Energy Agency (IAEA-N1, IAEACH7, IAEA-C3, and IAEA-600) and the USGS (USGS-25, USGS-40, and USGS-41). We included internal standards of purified methionine (Alfa Aesar, $\% \mathrm{C}=40.25, \quad \% \mathrm{~N}=9.39, \quad \delta^{13} \mathrm{C}=-34.6, \quad \delta^{15-}$ $\mathrm{N}=-0.9 \%$ ) and homogenized peach leaf (NIST $1547, \quad \% \mathrm{C}=46.79, \quad \% \mathrm{~N}=2.94 \quad \delta^{13} \mathrm{C}=-25.8 \%$, $\delta^{15} \mathrm{~N}=1.9 \%$ ) with all subsamples as quality controls. Stable isotope values are reported in standard $\delta$ notation of parts per mil (\%o) and are referenced to Vienna Pee Dee Belemnite (VPDB) for $\delta^{13} \mathrm{C}$ and to air for $\delta^{15} \mathrm{~N}$. Long-term records of internal standards yield an analytical precision of $0.03 \%$ for $\% \mathrm{~N}, 0.22 \%$ for $\% \mathrm{C}, 0.1 \%$ for $\delta^{15} \mathrm{~N}$, and $0.1 \%$ for $\delta^{13} \mathrm{C}$. Analyses were conducted at the University of Alaska Anchorage stable isotope facility.

To construct an age model, we radiocarbon dated terrestrial macrofossils and geochemically identified previously dated tephras throughout the master core.
To isolate terrestrial macrofossils, we sieved and rinsed (with distilled water) the remaining material in each of the 215 sediment core subsamples; macrofossils with adequate mass for AMS radiocarbon dating were sent to the Center for Applied Isotope Studies at the University of Georgia for analysis. We calibrated all raw dates using the IntCal13 terrestrial calibration curve in the CALIB Program, version 7.1 (Reimer et al. 2013; Stuiver et al. 2017; Stuiver and Reimer 1993). Tephras identified visually and by spikes in magnetic susceptibility were sampled and wet sieved to remove particles $<63 \mu \mathrm{m}$, and dried. We analyzed glass shards from tephra samples by electron probe microanalysis (EPMA) using a JEOL 8900 electron microprobe equipped with 5 wavelength $\mathrm{x}$-ray spectrometers at the USGS, Menlo Park, California. Standards for EPMA analysis included Si-RLS-132, $\mathrm{Fe}, \mathrm{Mg}, \mathrm{Ca}-\mathrm{VG} 2$ (basaltic glass), K, Al-Or1, NaTibAlbite, Cl-sodalite, P-Wilberforce apatite, Ti$\mathrm{TiO}_{2}$ and $\mathrm{Mn}-\mathrm{Mn}_{2} \mathrm{O}_{3}$. We attempted to identify 11 tephra events by geochemically correlating them to dated reference tephras archived at the USGS Alaska Tephra Laboratory and Data Center in Anchorage, AK. Our age model utilized all dated macrofossils and tephras and assumed a constant sedimentation rate between adjacent dated layers.

\section{Results}

Laminated brown and gray silts (Munsell colors: 5Y 5/2, 5 Y 6/1, 5GY 6/1; Goddard et al. 1975) intermixed with blue/gray clastic bands (Munsell colors: 5PB 7/2, 5B 7/1, 5B 7/6, 5B 5/6), black organic bands, and several tephra layers of varying color (Munsell colors: 5YR 3/4, 10YR 8/2,10YR 2/2) were common across cores (Fig. 2). All cores were dominated by silts $(0.002-0.05 \mathrm{~mm})$, but they also contained layers of very fine-grained sands $(0.05-0.125 \mathrm{~mm})$ and clays $(<0.002 \mathrm{~mm})$ (Fig. 2). Tephras were composed of 


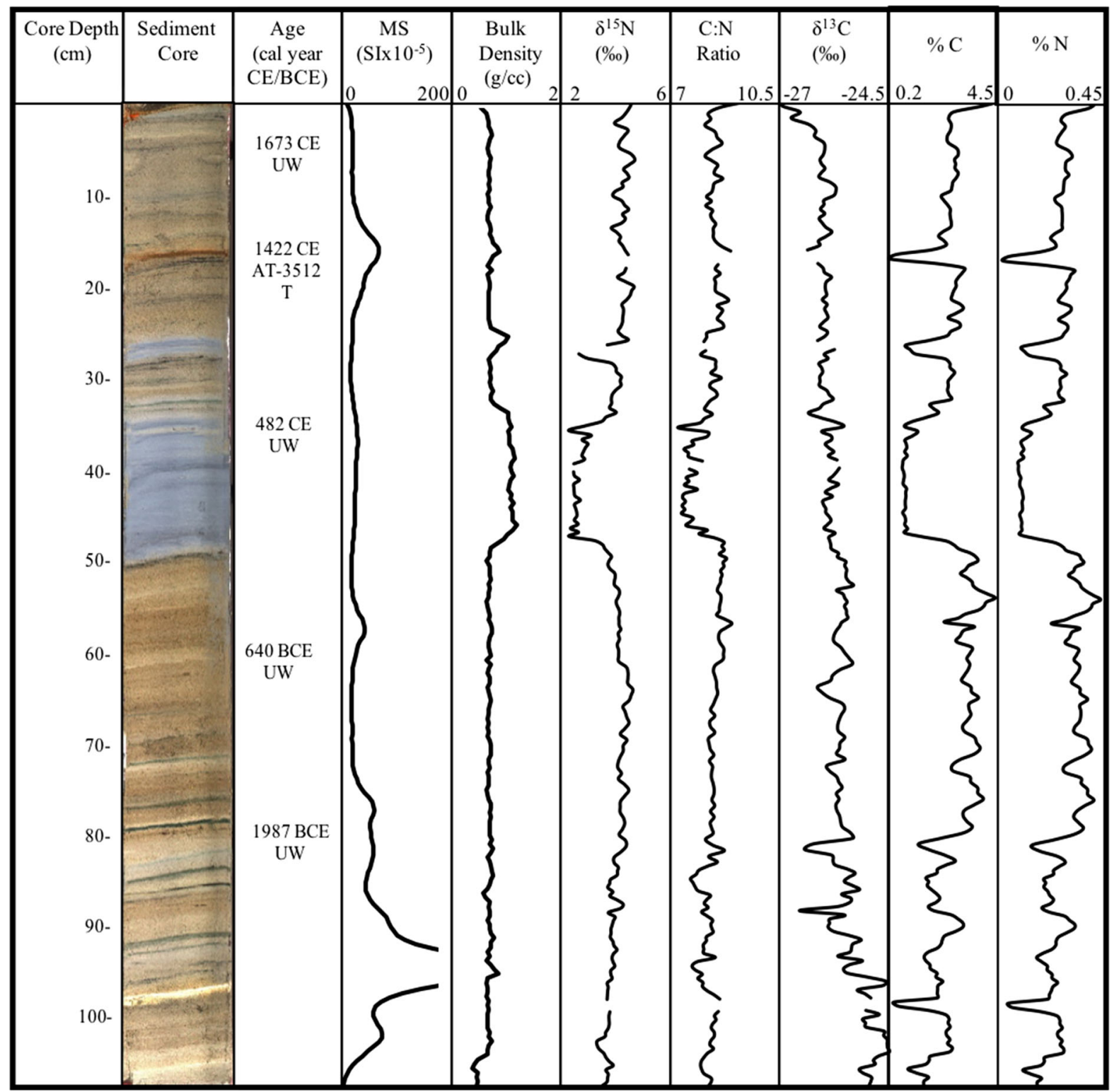

Fig. 2 Photograph showing sediment core stratigraphy from the Upper Russian Lake master core in relation to the dated layers used for the age model; magnetic susceptibility (MS) used to identify tephras; bulk density, an indicator of sediment type;

fine to medium-grained ash $(<0.0625-0.125 \mathrm{~mm}$; Fig. 2).

Our age model was based on 4 radiocarbon-dated wood fragments and 1 dateable tephra, for a total of 5 dated layers (Table 2). The macrofossils were found at depths of 5-80 cm below the lake floor and corresponded to ages between $229 \pm 24$ at $5 \mathrm{~cm}$ and $3626 \pm 23$ year BP at $80 \mathrm{~cm}$. The dateable tephra was sedimentary $\delta^{15} \mathrm{~N}$, a proxy for salmon abundance; $\mathrm{C}: \mathrm{N}$ ratio (by mass); $\delta^{13} \mathrm{C} ; \% \mathrm{C}$; and $\% \mathrm{~N}$. In the age column, $U W$ stands for unidentified wood and $T$ stands for tephra

a 2-cm-thick deposit centered at a core depth of $17 \mathrm{~cm}$, which correlated with a $505 \pm 25$ year BP tephra layer found in a peat core from Seldovia, Alaska (AT3508, unpublished data). Sedimentation rates, based on linear interpolation between each of the 5 dated layers, varied from 0.014 to $0.047 \mathrm{~cm} /$ year and was highest between the topmost and underlying dated layers (Fig. 3). At these relatively slow sedimentation 
rates, each $0.5-\mathrm{cm}$ subsample represents $10-34$ years and the dated portion of the core represents $\sim 4000$ years (Fig. 3).

$\mathrm{C}: \mathrm{N}$ (by mass) was relatively low (7.7-11.0 throughout the dated portion of the core), suggesting that organic matter was predominantly from aquatic sources, thereby indicating limited potential for alteration of MDN signals by inputs of terrestrial organic matter (Holtham et al. 2004). The $\delta^{13} \mathrm{C}$, which ranged from -27.2 to -24.5 , was consistent with aquatic sources, though it also generally fell within the range of terrestrial plants. The recent decline in $\delta^{13} \mathrm{C}$ to the lowest values observed in the record likely reflects the influence of anthropogenic $\mathrm{CO}_{2}$ in the atmosphere, i.e. the Suess effect (Verburg 2007).

The $\delta^{15} \mathrm{~N}$ values averaged $4.7 \%$ throughout the dated portion of the core, which is substantially higher than in salmon-free control lakes and generally consistent with expected values for similar spawning densities, suggesting that variation in $\delta^{15} \mathrm{~N}$ was related to MDN input (Finney et al. 2000; Rogers et al. 2013). For the first 1900 years ( $~ 2000$ BCE to 100 BCE) of the $\sim 4000$-year time series represented in the core, $\delta^{15} \mathrm{~N}$ averaged $4.9 \%$ (Figs. 2, 4). Over the period from $\sim 100 \mathrm{BCE}$ to $550 \mathrm{CE}, \delta^{15} \mathrm{~N}$ abruptly declined to an average of $2.7 \%$, which is closer to values $\sim 2.3 \%$ o observed in sediments of salmon-free reference lakes elsewhere in Alaska (Finney et al. 2002; Rogers et al. 2013) and suggests a significant, multi-centennial

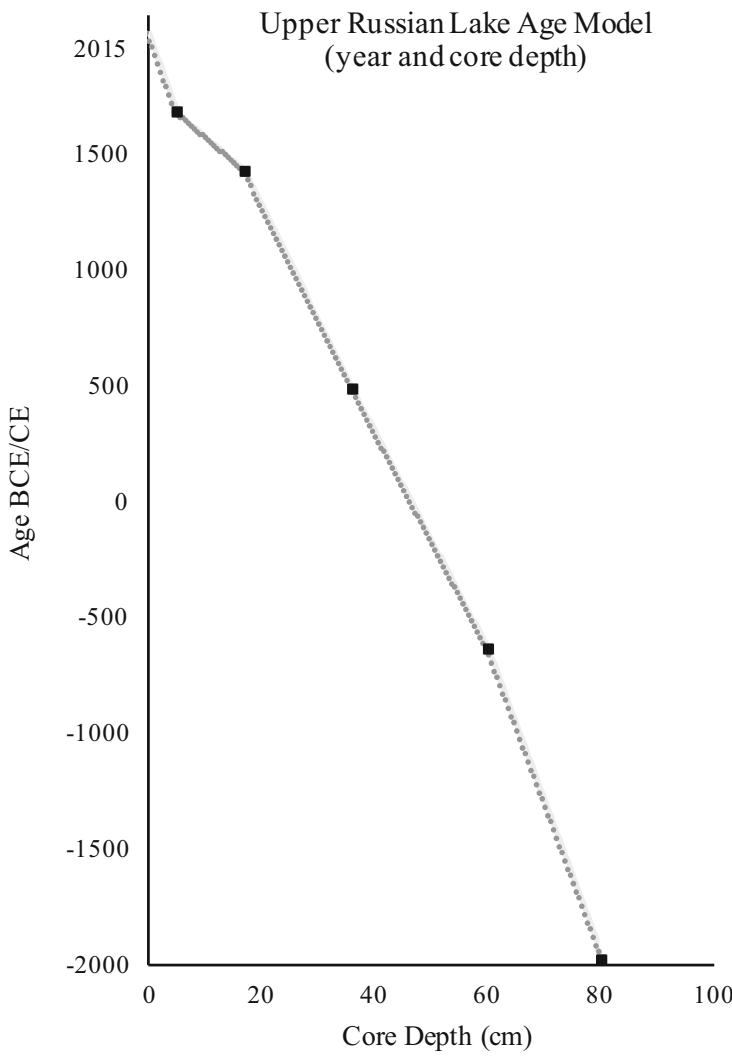

Fig. 3 Age at depth for the Upper Russian Lake master core, constructed from the 4 radiocarbon-dated macrofossils and 1 dateable tephra and assuming constant sedimentation rates between successive dated layers

Table 2 Radiocarbon sample material, core depth, measured age of sample and calibration output for 5 samples used to construct Upper Russian Lake age model

\begin{tabular}{|c|c|c|c|c|c|}
\hline $\begin{array}{l}\text { Sample } \\
\text { material }\end{array}$ & $\begin{array}{l}\text { Core depth } \\
(\mathrm{cm})\end{array}$ & $\begin{array}{l}\text { Age }\left({ }^{14} \mathrm{C}\right. \\
\text { years })\end{array}$ & $\begin{array}{l}\text { Median cal years } \\
\text { (CALIB 7.1) }\end{array}$ & $\begin{array}{l}\text { 2- } \sigma \text { age ranges, cal years } \\
\text { (CALIB 7.1) }\end{array}$ & $\begin{array}{l}\text { Relative age range } \\
\text { probability }\end{array}$ \\
\hline $\begin{array}{l}\text { Unidentified } \\
\text { wood }\end{array}$ & 5 & $229 \pm 24$ & $1673 \mathrm{CE}$ & $\begin{array}{l}1642-1679 \text { CE } \\
1764-1800 \\
1939-1950\end{array}$ & $\begin{array}{l}0.533 \\
0.398 \\
0.069\end{array}$ \\
\hline Tephra & 17 & $505 \pm 25$ & $1422 \mathrm{CE}$ & $1403-1443 \mathrm{CE}$ & 1 \\
\hline $\begin{array}{l}\text { Unidentified } \\
\text { wood }\end{array}$ & 36 & $1581 \pm 25$ & $482 \mathrm{CE}$ & 417-541 CE & 1 \\
\hline $\begin{array}{l}\text { Unidentified } \\
\text { wood }\end{array}$ & 60 & $2517 \pm 24$ & $640 \mathrm{BCE}$ & $\begin{array}{l}790-732 \text { BCE } \\
690-661 \\
649-545\end{array}$ & $\begin{array}{l}0.293 \\
0.159 \\
0.548\end{array}$ \\
\hline $\begin{array}{l}\text { Unidentified } \\
\text { wood }\end{array}$ & 80 & $3626 \pm 23$ & 1987 BCE & $\begin{array}{l}2114-2099 \text { BCE } \\
2037-1917\end{array}$ & $\begin{array}{l}0.025 \\
0.975\end{array}$ \\
\hline
\end{tabular}

All radiocarbon ages are given as calibrated ages in years BCE/CE 
decline of Upper Russian Lake sockeye salmon abundance. The $\delta^{15} \mathrm{~N}$ in sediments accumulated since this decline (550 CE-present) averaged 5.0\%, with the exception of another decline from $900 \mathrm{CE}$ to 1000 CE, during which $\delta^{15} \mathrm{~N}$ in sediments averaged $2.9 \%$. The relatively high values and narrow range in $\delta^{15} \mathrm{~N}$ prior to and since the decline, suggest that salmon were returning to the lake in numbers similar to present day during those intervals.

\section{Discussion}

Sediment $\delta^{15} \mathrm{~N}$ in Upper Russian Lake has fluctuated around a mean of $4.5 \%$ for most of the $\sim 4000$ years represented in our core, suggesting that spawner abundance has been relatively consistent on timescales similar to or greater than sampling resolution over much of this time period. A major multicentennial decline in inferred salmon abundance, however, occurred from $\sim 100 \mathrm{BCE}$ to $550 \mathrm{CE}$ followed by a shorter decline from $\sim 900$ to $1000 \mathrm{CE}$. These shifts coincide with inferred salmon declines in both Karluk and Akalura Lakes on Kodiak Island, $>400 \mathrm{~km}$ southwest of our study area (Fig. 4), the only other lakes with salmon reconstructions dating back to this time period (Finney et al. 2002). This finding provides further evidence for an ancient, prolonged and widespread decline in salmon production, and supports the hypothesis that high-magnitude, low-frequency climate patterns synchronize production regimes across the North Pacific (Finney et al. 2002).

In addition to unfavorable conditions at sea, it is possible that salmon declines in Upper Russian Lake were also associated with changes in its watershed. Concurrent with the salmon decline inferred from $\delta^{15} \mathrm{~N}$, the sediment character shifted towards finergrain materials with lower organic matter content (Fig. 2), reflecting glacio-lacustrine processes. With regional evidence of glacial advance during this time period (Wiles and Calkin 1994), it is possible that the primary inlet stream to Upper Russian Lake was impacted by glacial ice that extended northward from the nearby Harding Icefield. Inputs of silt-rich, turbid glacial meltwater could have led to degraded salmon spawning conditions in the inlet stream and, by limiting light penetration, to reduced sockeye salmon carrying capacity in the lake (Koenings et al. 1986; Milner and Petts 1994).

Most Alaska nursery lakes show clear trends toward lower $\delta^{15} \mathrm{~N}$ since the late $1800 \mathrm{~s}$, following the onset of commercial salmon fisheries (Finney et al. 2002; Rogers et al. 2013), which typically harvest half or more of each year's spawning run. Upper Russian Lake sediments, however, show no sign of such depletion. Several other nursery lakes that have been studied, however, also fail to display lower $\delta^{15} \mathrm{~N}$ in upper sediments, presumably a consequence of the relatively recent development of commercial fisheries
Fig. 4 Comparison of salmonreconstruction among UpperRussian Lake, and Akaluraand Karluk lakes on KodiakIsland (Finney et al. 2002)

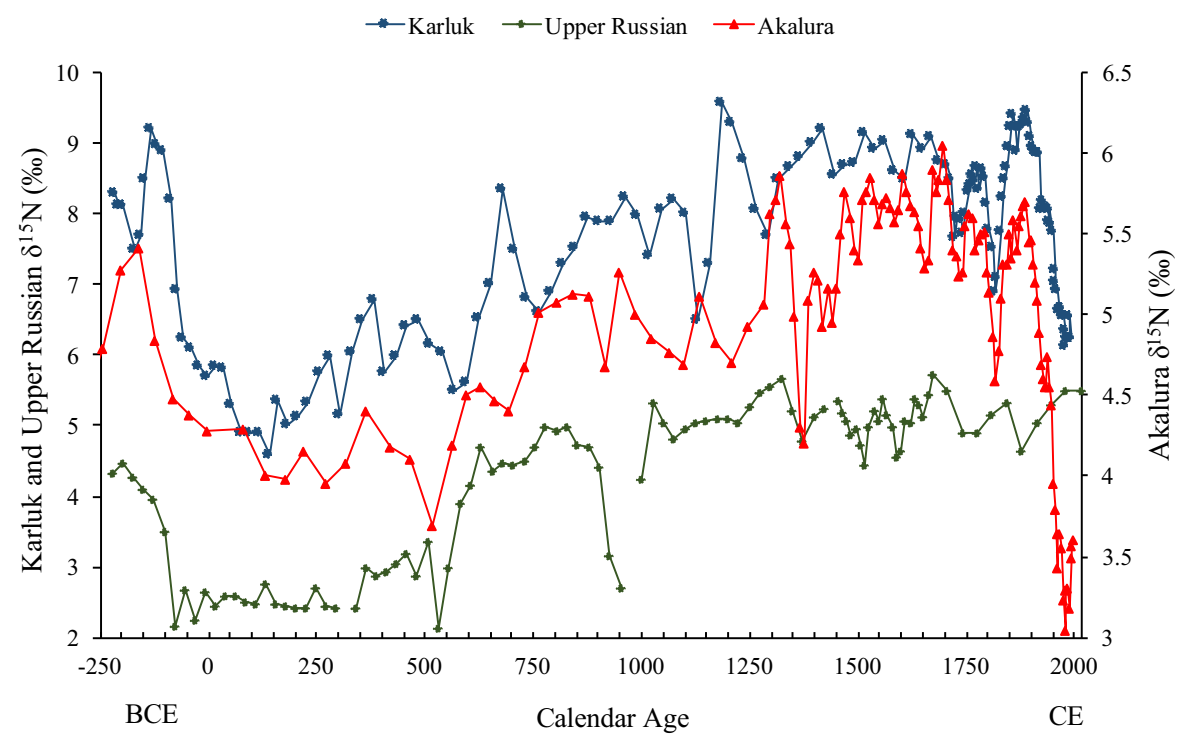


that intercept stocks bound for these lakes (Rogers et al. 2013). An unknown portion of the Russian River's late run has been harvested by Cook Inlet's commercial fisheries since they began, shown in recent years by genetic stock identification, to average 28\% (2006-2008 data; Eskelin et al. 2013), so it is possible that commercial harvest has not impacted escapement enough to elicit the dramatic ${ }^{15} \mathrm{~N}$ depletion seen in other systems. Harvest rates on Russian River salmon have presumably increased in recent decades (Schoen et al. 2017), with the growth of sport fisheries that harvest approximately $50 \%$ of the early run and $29 \%$ of the late run and a personal-use fishery that harvests $7 \%$ of the late run (Begich and Pawluk 2007; Eskelin et al. 2013; Fair et al. 2013). This additional harvest may be too recent to be reflected in Upper Russian Lake sediments (Rogers et al. 2013), especially given the relatively low temporal resolution of our core subsampling. Additionally, these fisheries developed during a period of favorable ocean conditions and exceptionally high abundance for many salmon stocks, including Cook Inlet sockeye salmon (Irvine and Ruggerone 2016).

Our results provide further evidence for synchrony in salmon production regimes at centennial timescales over the last few millennia (Finney et al. 2002). Fluctuations in Upper Russian Lake salmon abundance inferred from $\delta^{15} \mathrm{~N}$ over the last 500 years are, however, relatively minor compared to records from other Alaskan nursery lakes (Rogers et al. 2013). Resolving this scale of fluctuation is likely compromised because of the low time-resolution of our record, but it could also reflect the fact that individual systems may react differently to regional climate change on decadal scales (Rogers et al. 2013). The temporal resolution of our data are sufficient to compare over longer timescales, and suggest coherent patterns of higher magnitude and longer duration at centennial and longer scales.

In summary, our results from Upper Russian Lake, together with previous research (Finney et al. 2002), suggest dramatic multi-centennial periods of lower salmon abundance in multiple systems across a wide area of the northern Gulf of Alaska. Though reduced freshwater carrying capacity from increased glacial meltwater input may have played a role in the Upper Russian Lake salmon decline, the common MDN anomaly in other clear-water lakes suggests that altered ocean conditions are a contributing factor.
Further research into the ocean environment during these times may shed light on how climate influences salmon production in the ocean. As a working hypothesis, the climate conditions that led to significant first-millennium AD glacial advances (Wiles and Calkin 1994) in this part of the Kenai Peninsula (cold and/or wet conditions), may have created unfavorable ocean conditions during critical times during the marine phase of these stocks of Gulf of Alaska sockeye. Interestingly, these conditions were different from those during glacial advances in the Little Ice Age, a time for which most available sediment core data from Alaskan sites suggests high salmon abundance (Finney et al. 2002; Rogers et al. 2013). Our Upper Russian core, uniquely from a primarily clearwater lake with periodic glacial influence, also shows relatively high $\delta^{15} \mathrm{~N}$ during the Little Ice Age. Future climate projections and management strategies should focus on understanding how climate regimes not only impact prey availability for salmon at sea, but also influence local conditions for spawners and juveniles.

Acknowledgements This analysis was part of a larger project funded by Alaska EPSCoR National Science Foundation award \#O1A-1208927 and the State of Alaska. Support for Bruce Finney was assisted by NSF award \#1521365. We thank Kristi Wallace from USGS for tephra analysis, as well as use of her tephra lab for a variety of sampling activities. We acknowledge the many researchers who work for the Alaska Department of Fish and Game and collected long-term data on commercial and sport catch and escapement of Kenai River and Russian River salmon, and especially Mark Willette for providing initial guidance. We also thank Dr. David Fortin, Nore Preat, Koen Du Ryker, Phillip Kempf, Nicole Warner, Courtney Breest, Scott Cunfer, Nancy McCarthy, and Frank McCarthy for field and laboratory assistance. The findings and conclusionsin this article are those of theauthors and do not necessarilyrepresent the view of the U.S.Fish and Wildlife Service.

Open Access This article is distributed under the terms of the Creative Commons Attribution 4.0 International License (http:// creativecommons.org/licenses/by/4.0/), which permits unrestricted use, distribution, and reproduction in any medium, provided you give appropriate credit to the original author(s) and the source, provide a link to the Creative Commons license, and indicate if changes were made.

\section{References}

Begich RN and Pawluk JA (2007) 2007 Recreational fisheries overview and historic information for North Kenai Peninsula: fisheries under consideration by the Alaska Board of 
Fisheries, February 2008. Alaska Department of Fish and Game, Fishery Management Report No. 07-66, Anchorage

DeCino RD, Willette TM (2011) Juvenile sockeye salmon population estimates in Skilak and Kenai lakes, Alaska, by use of split-beam hydroacoustic techniques in September 2004. Alaska Department of Fish and Game, Fishery Data Series No. 11-13, Anchorage

DeCino RD, Willette TM (2014) Juvenile sockeye salmon population estimates in Skilak and Kenai lakes, Alaska, by use of split-beam hydroacoustic techniques, 2005 through 2010. Alaska Department of Fish and Game, Fishery Data Series No. 14-17, Anchorage

Eskelin A, Antonovich A, Barclay AW (2013) Upper Russian river late-run sockeye salmon run reconstructions, 2006-2008. Alaska Department of Fish and Game, Fishery Data Series No. 13-22, Anchorage

Fair LF, Willette TM, Erickson JW (2013) Review of salmon escapement goals in Upper Cook Inlet, Alaska, 2014. Alaska Department of Fish and Game, Fishery Manuscript Series No. 13-13, Anchorage

Finney BP (1998) Long- term variability of Alaskan sockeye salmon abundance determined by analysis of sediment cores. North Pac Anadromous Fish Comm Bull 1:388-395

Finney BP, Gregory-Eaves I, Sweetman J, Douglas MSV, Smol JP (2000) Impacts of climatic change and fishing on Pacific salmon abundance over the past 300 years. Science 290:795-799

Finney BP, Gregory-Eaves I, Douglas MSV, Smol JP (2002) Fisheries productivity in the northeastern Pacific Ocean over the past 2200 years. Nature 416:729-733

Geotek Limited. MSCL systems webpage. http://www.geotek. co.uk/products/mscl-s. Accessed April 2015

Goddard EN, Trask PD, De Ford RK, Rove ON, Singewald JTJ, Overbeck RM (1975) Rock-color chart. The Geological Society of America, Boulder

Gregory-Eaves I, Smol JP, Douglas MSV, Finney BP (2003) Diatoms and sockeye salmon (Oncorhynchus nerka) population dynamics: reconstructions of salmon-derived nutrients over the past 2200 years in two lakes from Kodiak Island, Alaska. J Paleolimnol 30:35-53

Holtham AJ, Gregory-Eaves I, Pellatt M, Selbie DT, Steward L, Finney BP, Smol JP (2004) The influence of flushing rates, terrestrial input and low salmon escapement densities on paleolimnological reconstructions of sockeye salmon (Oncorhynchus nerka) nutrient dynamics in Alaska and British Columbia. J Paleolimnol 32:255-271

Irvine JR, Ruggerone GT (2016) Provisional estimates of numbers and biomass for natural-origin and hatchery-origin pink, chum, and sockeye salmon in the North Pacific, 1952-2015. North Pac Anadromous Fish Comm Bull 1660: $1-45$

Koenings JP, Kyle GB (1997) Consequences to juvenile sockeye salmon and the zooplankton community resulting from intense predation. Alask Fish Res Bull 4(2):120-135

Koenings JP, Burkett RD, Kyle GB, Edmundson JA, Edmundson JA (1986) Trophic level responses to glacial meltwater intrusion in Alaskan lakes. In: Cold regions hydrology symposium. American Water Resources Association, pp 179-194
Milner AM, Petts GE (1994) Glacial rivers: physical habitat and ecology. Freshw Biol 32:295-307

Nelson. DC (1983) Russian river sockeye salmon study. Alaska Department of Fish and Game, Anadromous Fish Studies 24(AFS 44-9), Annual Report 1982-1983. Juneau

Reimer PJ, Bard E, Bayliss A, Beck JW, Blackwell PG, Bronk Ramsey C, Buck CE, Cheng H, Edwards RL, Reiedrich M, Grootes PM, Guilderson TP, Haflidason H, Hajdas I, Hatté C, Heaton TJ, Hogg AG, Hughen KA, Kaiser KF, Kromer B, Manning SW, Niu M, Reimer RW, Richards DA, Scott EM, Southon JR, Turney CSM, van der Plicht J (2013) IntCal13 and MARINE13 radiocarbon age calibration curves $0-50,000$ years calBP. Radiocarbon. https://doi. org/10.2458/azu_js_rc.55.16947

Rogers LA, Schindler DE, Lisi PJ, Holtgrieve GW, Leavitt PR, Bunting L, Finney BP, Selbie DT, Chen G, Gregory-Eaves I, Lisac MJ, Walsh PB (2013) Centennial-scale fluctuations and regional complexity characterize Pacific salmon population dynamics over the past five centuries. Proc Natl Acad Sci (USA) 110:1750-1755

Schoen ER, Wipfli MS, Trammell EJ, Rinella DJ, Floyd AL, Grunblatt J, McCarthy MD, Meyer BE, Morton JM, Powell JE, Prakash A, Reimer MN, Stuefer SL, Toniolo H, Wells B, Witmer FDW (2017) Future of Pacific Salmon in the face of environmental change: lessons from one of the world's remaining productive salmon regions. Fisheries 42:538-553

Shields P, Dupuis A (2016) Upper cook inlet commercial fisheries annual management report, 2015. Alaska Department of Fish and Game, Fishery Management Report No. 16-14, Anchorage

Spafard M, Edmundson J (2000) A morphometric atlas of Alaskan lakes: Cook Inlet, Prince William Sound, and Bristol Bay areas. Alaska Department of Fish \& Game, Commercial Fisheries Division, Regional Information Report No. 2A00-23, 13p + 82 maps

Stuiver M, Reimer PJ (1993) Extended 14C Database and revised CALIB 3.0 14C calibration program. Radiocarbon 35:215-230

Stuiver M, Reimer PJ, Reimer RW (2017) CALIB 7.1 marine reservoir correction database. http://calib.org. Accessed Jan 2016

Tobias T, Willette TM (2013) An estimate of total return of sockeye salmon to Upper Cook Inlet, Alaska, 1976-2008. Alaska Department of Fish and Game, Division of Commercial Fisheries, Regional Information Report 2A13-02, Anchorage

Verburg P (2007) The need to correct for the Suess effect in the application of $\beta 13 \mathrm{C}$ in sediment of autotrophic Lake Tanganyika, as a productivity proxy in the Anthropocene. J Paleolimnol 37:591-602

Wiles GC, Calkin PE (1994) Late Holocene, high-resolution glacial chronologies and climate, Kenai Mountains, Alaska. Geol Soc Am Bull 106:281-303

Willette TM, Shields P (2015) 2016 upper cook inlet sockeye salmon forecast. Alaska Department of Fish and Game, Division of Commercial Fisheries News Release 